Freedom and Fulfillment

$\longrightarrow$ 



\title{
Freedom and Fulfillment
}

\section{PHILOSOPHICAL ESSAYS}

\author{
Joel Feinberg
}

PRINCETON UNIVERSITY PRESS PRINCETON, NEW JERSEY 
Copyright $(1992$ by Princeton University Press Published by Princeton University Press, 41 William Street, Princeton, New Jersey 08540

In the United Kingdom: Princeton University Press, Chichester, West Sussex

Library of Congress Cataloging-in-Publication Data

Feinberg, Joel, 1926-

Freedom and fulfillment : philosophical essays / Joel Feinberg.

p. $\mathrm{cm}$.

Includes index.

1. Ethics. 2. Social ethics. I. Title.

BJ1012.F42 $1992 \quad 170-$ dc20 91-46753

ISBN 0-691-07412-7

ISBN 0-691-01924-X (pbk.)

All Rights Reserved

This book has been composed in Linotron Galliard

Princeton University Press books are printed on acid-free paper and meet the guidelines for permanence and durability of the Committee on Production Guidelines for Book Longevity of the Council on Library Resources

First Princeton Paperback printing, 1994

Printed in the United States of America

35779108642 